Article

\title{
Formal Education of Asylum Seeker Children in Belgrade, Serbia: Expanded Meaning of Social Inclusion
}

\author{
Teodora Jovanović $(\mathbb{D}$
}

The Institute of Ethnography of the Serbian Academy of Sciences and Arts, 11000 Belgrade, Serbia; teodora.jovanovic@ei.sanu.ac.rs

Received: 23 April 2019; Accepted: 2 July 2019; Published: 6 July 2019

\begin{abstract}
Formal education of asylum seeker children in Serbia officially started in September 2017, when the consequences of European border regime became more obvious. In spite of the official attitude that Serbia is a transit country, there was a pressure to improve integration policies regarding migration, since a lot of people wanting to seek asylum in European Union have remained in Serbia for months. Educational inclusion is the aspect of asylum seekers' integration in which the most resources and effort was invested. In this article, I try to define the notions of social and educational inclusion in relation to integration policies of asylum seekers coming from different cultural backgrounds and in relation to existing educational inclusion policies.
\end{abstract}

Keywords: inclusion; intercultural; education; asylum seeker; difficulty; diversity

\section{Introduction}

When it comes to the notion of social inclusion, "in recent years it has taken on a broader usage in response to the increasing diversity within school communities, including cultural and linguistic diversity" (Taylor and Sidhu 2012, p. 53). Scholarly approaches to educational inclusion vary among the context of physical disability, cognitive disability, multi-cultural and multi-lingual education. In this paper, multi-cultural and multi-lingual education is considered, with the focus on asylum seekers from Afghanistan, Iran, Syria, Iraq, Pakistan, and other countries from the Middle East, who live in reception centers in Serbia. I am examining the process of asylum seeker's enrollment in elementary schools in Belgrade. Three main themes are considered through interviews with research participants and literature review: the beginning of formal education of asylum seeker children in Serbia, intercultural education, and the notion of social inclusion. The central research question is how the social inclusion is understood in regard to cultural diversity. Various perspectives are taken into account: teachers', NGO representatives', government officials', refugees' and scholars'. The objective of this paper is to provide understanding of how the notions of educational 'inclusion' and 'interculturality' are used in the context of formal education of asylum seeker children in Belgrade.

The argument offered in this paper is that there are two ways to define 'inclusion' in Serbia and that these two ways have to be conceptually divided-the first is inclusion in a narrow sense and the second is inclusion in a wide sense. Inclusion in a narrow sense refers to the context of physical and cognitive disability and implementation of individual education plan (IEP), while inclusion in a wide sense refers also to the context of multi-cultural and multi-lingual diversity in the classroom.

In the introduction, I define the research question and objective and present the structure of the paper. The second part is methodology, where I explain methods behind this research and show who are my informants. In the third part, I discuss literature review, relevant theoretical problems that are connected with my fieldwork and scholary approach to inclusion. Next, I explain the legal 
context of this research, concerning asylum and Serbia-specific approach to inclusion. In the fifth part, I present the results, through answers of my informants and explain the meaning of their answers. In the conclusion, the most important insights are highlighted.

\section{Methodology}

In this anthropological research, case study methodological approach is chosen, combined with ethnographic observation, semi-structured interviews, and literature analysis. The research was conducted in three schools in Belgrade and each school represents one case study. By following an example of similar research from Australia, the first criteria for school selection was their reputation for work with asylum seeker children (Taylor and Sidhu 2012, p. 45). The second criteria for selecting schools was the proximity to Krnjača reception center, where asylum seekers live, and consequently the number of asylum-seeking children enrolled. The third criteria was the 'inclusiveness' of the school. As a result, I visited those three schools and conducted interviews with key support staff.

Data collection was not limited to schools. Interviews with the representatives of the Ministry of Education, Science and Technological Development of Serbia who created and realized the Professional Instruction for Inclusion of Refugee/Asylum Seeking Students in the System of Education and Upbringing were also conducted. From NGO representatives, additional explanations and interpretations of school enrollment process were collected. Also, important insights from parents were gained in Krnjača reception center (see Table 1 "Research Participants").

The focus of the semi-structured interviews with school staff and the representatives of the Ministry of Education, Science and Technological Development were their interpretations of 'inclusion' and their experience of asylum seeker children school enrollment process. The interviews with asylum seeker parents from Krnjača reception center were not conducted for the purpose of this particular paper, but for my $\mathrm{PhD}$ research. However, during interviews, many of my asylum seeker informants talked about this aspect of their family life in Sebia, so I used their insights in this research. I selected only statements of asylum seeker parents whose children go to the schools in which I conducted research for this particular paper.

The limitation of the study which needs to be clarified is that my point of view is shaped by anthropological theoretical methodological frameworks. First, the research topic of this study, social and educational inclusion, is not traditionally explored by anthropologists, but by academics in the field of education science (pedagogy), psychology, defectology, or sociology. Therefore, my interest on certain aspects of this topic comes mainly from the spectrum of theories on cultural diversity and migration. Second, anthropology is a discipline which uses qualitative research methods, so the analysis is focused on research participants' answers, stories, and explanations, instead of quantitative measures. In total, 17 interviews are analyzed in this paper.

Table 1. "Research Participants".

\begin{tabular}{ccc}
\hline Research Participants & Men & Women \\
\hline Number of individual research participants: $\mathrm{N}=17$ & 3 & 14 \\
\hline
\end{tabular}

Teachers (5), school pedagogists (3), school psychologists (1), representatives of the Ministry of Education, Science and Technological Development of Serbia (3), representatives of NGOs (2), asylum seeker parents (3)

\section{Discussion: Social Inclusion through Education}

One of the most general ways to think about inclusion is to conceive it as a response to exclusion (Ainscow et al. 2006, p. 15). The marginalization of socially excluded groups and individuals is based on their ethnic, religious, gender, class, or other identity. Social exclusion is often manifested through restricted access to educational opportunities (Forbes and Sime 2016, p. 2). However, "inclusion cannot simply be constructed as the opposite of exclusion", because there is a constant interplay and negotiation between these two processes (Armstrong et al. 2011, p. 36). 
Scholarly approaches to educational inclusion vary among the context of physical disability, cognitive disability (autism, down syndrome, etc.), behavioral and emotional disorders, and multicultural and multi-lingual diversity (Ainscow et al. 2006, p. 15; OECD 2005, p. 14). The goal of formal education of asylum seeker children is to include them into regular classrooms even though they come from different cultural backgrounds and do not speak the native language.

There are three assumptions that prevail in understanding of social inclusion of refugee/asylum seeker children through education in literature. First is that "education might play a role in promoting social cohesion in societies that are increasingly diverse, socially and culturally" (Armstrong et al. 2011, p. 29). The other one is that formal education is supposed to be one of the "protective factors" for refugee and displaced children (Mikuš Kos 2005, p. 16; Farrell 2011, p. 206). The third one is about mental health of refugee children, but many authors oppose to this one, because it tends to reduce refugee children to traumatized subjects. Labeling refugee students as 'traumatised' or 'vulnerable' impedes real analysis of their experiences. By categorising the refugee "as a medicalised subject of trauma" and as "the welfare subject whose survival is reliant on the benevolence of the state" inequalities are masked and prospects for independence reduced (Taylor and Sidhu 2012, pp. 43-44).

In other words, insisting on psychological weakness of refugee children reinforces stereotypes and makes them even more socially isolated. This kind of labeling goes hand in hand with assumption that refugee children need a special treatment in schools because of their vulnerability, which is something that many of my informants emphasized as a difficulty. "Not only that Serbian government provides formal education to migrant children, they are also educating teachers and educators on this topic and how to include migrant children in the informal education" (Stajić 2018, p. 31). Many of my informants went through these training courses, where they were taught that asylum seeker children are 'vulnerable'.

In order to avoid the term 'inclusion', because traditionally it implies some kind of disability, I believe that the term 'inctercultural education' should be used instead, when it comes to cultural and linguistic diversity in classroom. Policy approaches to intercultural education vary from country to country (Catarci 2014, p. 99), but here, the intercultural education is theoretically defined as an approach to education which respects diversity, equity, solidarity, cooperation, and participation, so that all students can achieve their potential and participate in society (Vranješević and Frost 2016, p. 65). Basically, it is a concept similar to inclusion, but instead of 'difficulty', the term 'diversity' is used, since it refers to ethnical/cultural difference. Intercultural education is basically inclusive education for the cultural 'Other'.

There are four levels of integration of multicultural content: the contributions approach, the additive approach, the transformation approach and the social action approach; plan and program for refugee/asylum seeker education in Serbia can be categorized as "the additive approach" (Banks 2010, p. 240). This approach allows the teacher to put content that refers to various ethnic groups in class into curriculum without restructuring it. Planning and programing is the same as for Serbian children, but teachers are organizing extra classes for asylum seeker children so they can follow classes, and they are also trying to stimulate discussions about the cultures to which asylum seekers come from. Also, on school walls I have noticed multilingual inscriptions prescribed in the Professional Instruction for Inclusion of Refugee/Asylum Seeking Students in the System of Education and Upbringing (Stanojković et al. 2017, p. 32). The purpose of these inscriptions is to encourage local children to embrace foreign cultures and languages.

It is noticed that the 'interculturality' of schools depends on their location. In Belgrade's suburban settlements such as Borcha, there are more ethnic minority groups (Roma, Goranci, Albanians, etc.). Ethnic minority groups in Serbia were initially moved to work in industrial sectors, located on the town periphery (Maksin-Mićić 2006). Also, apartments are cheaper in Borcha compared to Belgrade city center, and since many families that are ethnic minorities and immigrants belong to the working class, they are settled in suburban settlements outside the city center. This kind of spatial arrangement is the reflection of power relations between ethnic groups and their roles in the society structure. 
Cities, suburbs, and schools deploy forms of knowledge which further produce and reproduce social relationships and therefore social roles (Forbes and Sime 2016, p. 2).

The difference between 'integration' and 'inclusion' is often a subject of debate in round tables, seminars, classes, and handbooks concerning migration in Serbia. The most frequent explanation is that integration is simply physical presence of excluded groups, and that inclusion means changing values, attitudes, policies, and practices (Polat 2011, p. 50). In terms of education, "the perspective of 'inclusion' generated a critique of special education" (Armstrong et al. 2011, p. 31). OECD classification distinguishes disabilities, learning difficulties and disadvantages, instead of "special educational needs" (OECD 2005). Difficulties and disadvantages are commonly used to describe refugee children's obstacles to education.

The most fruitful approach to inclusion in education is acheived when it is combined with "capability approach", defined by Martha Nussbaum. Her definition of capability approach is an alternative to human rights approach. The practical result of this philosophy is "Education for All" (EFA), a global movement established by UNESCO. The central term of capability approach to inclusion is the idea of social justice (Polat 2011), connected to "individual's ability to proactively participate in politics and society" (Forbes and Sime 2016, p. 5). However, only one of my informants, the representative of an NGO dedicated to economic and social rights, understands inclusion in this way.

The discussions can be simplified to the following formula: multiculturalism versus interculturalism eguals integration versus inclusion. On the one side, there are multiculturalism and integration. These two concepts acknowledge the presence of 'the Other' in society and education, but they are reduced to the physical placement. On the other side, interculturalism and inclusion are more relational concepts. The school psychologist at the 'Jovan Ristić' school explained to me that multiculturalism is when people from different cultures live next to each other, but there are no interactions, while interculturalism is when they communicate and establish relationships. Multiculturalism and interculturalism refer to society in general, while integration and inclusion are discussed in educational sphere. However, the terms 'integration' and 'inclusion' often designate the proccesses of refugee adaptation, not only in schools, but in broader society. This is what produces confusion in contemporary 'inclusion vs. integration' debates-we are not always sure of what inclusion or integration we talk about.

\section{Background: Refugees and Inclusive Education in Belgrade}

Two distinct processes led to inclusion of asylum seeker children in Serbian education system. First is the transition of asylum seeker children from reception into schools. The second one is the transition from the old 'defectology' model and emphasis on 'special needs' to a certain policy on educational inclusion, which on first sight has nothing to do with refugees/migrants/asylum seekers, but it is connected to the way in which educational policies are tailored and in which the term 'inclusion' is understood.

After the so-called long migration summer in 2015 (Milan and Pirro 2018), the presence of migrants from the Middle East and Africa became apparent in Serbia. The formalized corridor established in early summer 2015 enabled refugees to legally cross the Balkans from northern Greece to Western Europe (Beznec et al. 2016, p. 4). The closure of this organized corridor in March 2016 resulted in people being unwillingly stuck in Serbia (Stojić Mitrović 2019, p. 17). Since then, migrants have resided both in informal settlements and state-run reception centers in Belgrade. Migrants who are settled in reception centers in Serbia are categorized as asylum seekers. By September 2017, most of the migrants from Afghanistan, Pakistan, Syria, Iraq, Iran, etc. were in reception and asylum centers, therefore they are called 'asylum seekers' (Lažetić and Jovanović 2018).

Belgrade was not the first town in Serbia in which asylum seeker children were enrolled in elementary schools. The first asylum seeker children were enrolled in 2013, in Bogovađa (Vranješević and Simić 2018, p. 1). In 2014 and 2015 several children were enrolled in the education system, but more systematic inclusion process of asylum seeker children in formal education has officially 
started in August 2016, when the Ministry of Education, Science and Technological Development of the Republic of Serbia sent a letter to school managements to provide the enrollment of asylum seeker children. In May 2017, the Professional Instruction for Inclusion of Refugee/Asylum Seeking Students in the System of Education and Upbringing was issued by the same ministry (Stanojković et al. 2017, pp. 11-12). In Septebmer 2017, almost 700 children from reception and asylum centers in Serbia enrolled in schools (Janković 2017). According to the representative from the Ministry of Education, Science and Technological Development, the education of asylum seeker children was obligatory, but the conditions for that were not provided before September 2017.

Several national and international laws constitute a legal framework for education and inclusion of asylum seeker children. Primary education is mandatory and free in Serbia. A right to education for everyone is guaranteed in the Constitution of The Republic of Serbia, article $71,{ }^{1}$ in the Serbian Law on Primary Education, article $4{ }^{2}$ and in the Law on Foundations of Educational System, article $3^{3}$. In order to ensure optimal inclusion of students, according to the Serbian Law on Primary Education, article 64, schools are obliged to remove physical and communication obstacles and insure additional support in education for children who have learning difficulties. In the Law on Asylum and Temporary Protection, article 55, it is stated that asylum seeker have the right to free primary and secondary education ${ }^{4}$. Other relevant laws and by-laws which institutionalize educational inclusion of asylum seeker children are the Law on Non-Discrimination and Rulebook on more detailed criteria for recognizing forms of discrimination by an employee, child, student or a third person in an educational institution. International legal documents which recommend each child's entitlement to education are Convention on the Rights of the Child, International Convention on the Protection of Rights of Workers and Migrantsand Their Family Members and Salamanca Statement.

Many people think that the distinctive characteristic of educational inclusion in Serbia is the adoption of individual education plan (IEP) (Spasenović and Maksić 2013, p. 212). There are no individual education plans for asylum seeker children, but there is a student support plan (Stanojković et al. 2017, p. 53). The implementation of individual education plan is, therefore, specific for inclusion in narrow sense (related to the context of disability and behavioral disorders), while the implementation of student support plan is specific for expanded meaning of inclusion (related to including asylum seeker children).

Changing both asylum policies and inclusive education policies are among requirements for Serbia's accession to the European Union. Fundamental to the development of asylum and inclusive education policies is compliance with the EU legislative acquis (Macura Milovanović et al. 2014, p. 37). The adoption of inclusive education policies also meant transformation from a 'special needs' to an 'inclusive' approach, which was followed by the closing down of special schools in Serbia. However, a large number of people who work within special education field is being produced. This is because 'defectologists' are graduate-trained in a separate faculty of Belgrade University (Radoman et al. 2006, p. 159). The 'defectology' versus 'inclusion' debate is important for understanding 'inclusion' in narrow sense. Inclusive education is a relatively new concept and sometimes it is considered to be in opposition to the previously established educational practices and policies of special education and defectology.

1 Constitution of the Republic of Serbia. In RS Official Gazette, no. 83/06, 30 September 2006. Available online: https: //www.refworld.org/docid/4b5579202.html (accessed on 9 April 2019).

2 The Law on Primary Education. In RS Official Gazette, no. 55/13, 25 June 2013. Available online: https://erasmusplus.rs/wpcontent/uploads/2015/03/Primary-Education-Law-ENGLESKI.doc (accessed on 9 April 2019).

3 Education for Migrant Students in the Republic of Serbia. The Ministry of Education, Science and Technological Development of the Republic of Serbia, November 2017. Available online: http://www.mpn.gov.rs/wp-content/uploads/2017/11/za-sajtObrazovanje-ucenika-migranata-u-RS-novembar-2017-eng.pdf (accesses on 10 April 2019).

4 The Law on Asylum and Temporary Protection. In RS Official Gazette, no. 24/18, 26 March 2018. Available online: http://www.unhcr.rs/media/docs/2018/LawOnAsylumAndTemporaryProtectionRS.pdf (accessed on 9 April 2019). 
EU accession negotiations are composed of 35 chapters, of which Chapter 23 and Chapter 24 are concerned with migration related issues (Stojić Mitrović 2019, p. 21). Changes in migration and asylum policies were direct results of legal harmonization with EU policies. Asylum law in Serbia exist from 2008-before that, the general public was not concerned with the matter of asylum seekers, refugees and migrants (Stojić Mitrović 2019, p. 19), except in the emigration context (Serbia is more of an emigration than an immigration country).

\section{Results: Inclusive Schools in Belgrade}

In this section, first I will present five steps necessary for asylum seekers' enrollment in schools and explain how these five steps are realized in three schools. Then, I will specify some stories from research participants that tackle the issue of cultural and language diversity. Finally, I will show how school staff and government officials define 'inclusion'.

Selected schools are the examples of refugee inclusion in formal education (Stanojković et al. 2017). The research for this paper was conducted in three elementary schools: 'Jovan Ristić' and 'Rade Drainac' in the Borcha area, and 'Branko Pešić' in the Zemun area. These schools have a reputation for their work with asylum seeker children. All three schools have been involved in pilot projects for refugee and asylum seeker children formal education process, which means that all of them had asylum seeker children in classrooms before the formal start of inclusion policy in September 2017:

First asylum seeker students came in January 2016. That was the first group. They were unaccompanied boys, seven of them. After that, all children were children from the families. We applied to the project by ourselves. (School psychologist, 'Jovan Ristić' school)

We started while it was still a pilot project, in December 2016, it wasn't official yet. We were one of the 10 schools which participated in that project. (School pedagogist, 'Rade Drainac' school)

'Branko Pešić' school also received first asylum seeker students in school year 2016/17. The Professional Instruction for Inclusion of Refugee/Asylum Seeking Students in the System of Education and Upbringing issued by the Ministry of Education, Science and Technological Development is based on the experiences from these schools while they were at pilot project phase. Many text boxes in the handbook for schools in realization of the Professional Instruction (Stanojković et al. 2017) contain stories from these three schools.

The Professional Instruction for Inclusion of Refugee/Asylum Seeking Students in the System of Education and Upbringing defines steps necessary for enrollment and monitoring process. ${ }^{5}$ The first step is to submit a request for enrollment. This should be done by a parent or a guardian, or social worker, if the child is unaccompanied. In practice, asylum seeker parents rarely come to school and submit a request by themselves. Instead, school staff sends a translated form through NGO staff (mainly farsi or arabic interpreters, who help children in schools) to a reception center, which parents sign and send back to school. Humanitarian worker who accompanies asylum seeker children from reception center to school said that it was not easy to persuade some parents to enroll their daughters in schools:

There are also girls. That is the biggest difference between their school and our school. We put a lot of effort to convince some parents of girls to enroll them in school. It is a big success for them, that they let the girls to go to the same school as boys from Afghanistan... Because there, they are separated. They either go to separated schools or to different shifts in

5 The Ministry of Education, Science and Technological Development of the Republic of Serbia. 2017. Professional Instruction for Inclusion of Refugee/Asylum Seeking Students in the System of Education and Upbringing. Available in Serbian at: http://www.mpn.gov.rs/strucno-uputstvo-za-ukljucivanje-ucenika-izbeglicatrazilaca-azila-u-sistem-obrazovanja-ivaspitanja/ (accessed on 9 April 2019). 
the same school. One shift only girls, other shift only boys. (Humanitarian worker, Danish Refugee Council)

Before the interview with humanitarian worker from DRC, I was not fully aware of the fact that children are separated by gender in schools in Afghanistan. Her statement helped me to understand why one father that I interviewed was so worried about his daughter's wellbeing in schools. He told me that his daughter (17) stopped going to school. I asked what was the problem, and he said "Serbian guys no problem. All problem is another single guys Afghani and Pakistani" (Asylum seeker from Afghanistan, 41). The inclusion in Serbian schools, where it is normal that boys and girls go to same classes, means that parents and children need to adapt themselves to different cultural norms. In other research, it is suggested that "migrant childred think that schools in Serbia differ from the ones they had attended in the countries they had come from because there is no corporal punishment and, notably, the rights of the child and their opinions are respected" (Vranješević and Simić 2018, p. 6).

Besides the signed form, parents need to show a certificate on registration from police and health report from doctor in reception center. Next, an expert team in the school should make the plan of support. The third step is the assessment of previous knowledge. This step is crucial for deciding in which grade the asylum seeker child will be enrolled. Sometimes it is hard to determine the grade:

There are two difficulties that asylum seeker children need support for: language and holes in knowledge... Because some of them didn't go to school at all, some of them went inordinately, some of them went to informal schools... And different things are being taught there. So they need tailored program, so they can understand, but also this new knowledge should lean on their previous knowledge. So, in that sense, this is similar to inclusion (i.e. inclusion in narrow sense). But at the end, the biggest problem is language. (School psychologist, 'Jovan Ristić' school)

Fourth, the plan of support is elaborated in more detail. The final step is monitoring and documenting in order to make a portifolio in English, which serves as certificate that asylum seekers show to schools in destination countries. The purpose of the certificate is to provide a proof that children were going to school during their journey to destination country.

Education plays important role not only for asylum seeker children, but also for their parents. The school pedagogist from 'Rade Drainac' and school psychologist from 'Jovan Ristić' both said that they have experience with asylum seeker families which think that education is very important and who put an extra effort. NGO ADRA Community Centre in Borcha organizes extra classes for children from Krnjača reception center and helps them to do homework. An asylum seeker from Krnjača reception center, whose children went to 'Rade Drainac' school, emphasized the importance of education:

I am an educated person, I have university degree. I am already 40+, I don't want more. My time is over, partially. But my children need to have good education, in Europe. I have friends and family there. They will help me with my children's education ... My children like school here, they go every day, without any delay ... And they have learned a lot. Especially my small children. All of them have talent. For all subjects, especially mathematics, English, physics. They are good ... We have 12 grades in Afghanistan. My daughter is going to ADRA school, she only finished 10 grades in Afghanistan. My baby son learned a lot of Serbian ... And he knows English. Some of his classmates don't know English ... So he taught them English and they taught him Serbian! (Asylum seeker from Afghanistan, 45)

In order to explore characteristics of schools with inclusive programs in Belgrade in regard to cultural diversity, we must look beyond the education of asylum seekers and ask about other particular groups. In 'Jovan Ristić' school, there are around 80 students of Gorani people ethnic minority. 'Rade Drainac' is a school where there are five Roma children per class: 
There are a lot of Roma students in our school. But Roma students mostly know Serbian language. So, it isn't the same. It isn't even similar. Simply, you get children who at the moment of their arrival don't know a single word in Serbian. (School pedagogist, 'Rade Drainac' school)

Special pedagogist in 'Branko Pešić' said that the school is not specialized for any particular group, but by observing the school, it was obvious that almost all students in school are Roma. I had an informal conversation with several Roma boys in front of the 'Branko Pešić' school. Some of them are not fluent in Serbian language, because they lived in Germany and Austria for most of their lives and now they are back in Serbia due to EU readmission agreement. Lack of competence in Serbian makes it difficult for Roma children to do well in school (Filipović et al. 2010, p. 263), so they are also subjects of educational inclusion policies. Regarding the 'inclusiveness' of this school, special pedagogist said that:

All children all included here ... Everybody have some difficulties in functioning in some aspect of life ... It might be learning difficulty, behavior problem, communication difficulty, physical disability ... Here we have children with one kind of problem and children with other kind of problem. (Special pedagogist, "Branko Pešić" school)

'Branko Pešić' school is the only school in this research that has a special pedagogist employed. A special pedagogist is a person who has a degree of the Faculty for Special Education and Rehabilitation and who is trained to work with children with difficulties and disadvantages. This school is different than other two included in this research. All asylum seeker children who go to 'Branko Pešić' school are 14+ years old, which means that asylum seeker children who are enrolled in this school are the who are too old for primary school. Cultural differences in terms of education, documented in this research, unquestionably influence on of asylum seekers' perception on schools in Belgrade. These differences are the structure of education system (e.g., the grades in primary school), gender stratification (e.g., girls and boys do not go together in school), subjects in schools (e.g., 'holes' in knowledge), and language (e.g., the 'language barrier'). Generally, the employees in these schools share similar values, related to inclusion, tolerance, and multicultural education. All of them praised asylum seeker children for their fast learning of Serbian language. They all said that at the beginning there were some minor incidents (e.g., between asylum seekers and Roma children), but that now everything goes fine. The conflict between cultural relativism and inclusiveness can be perceived as a reflection of a wider opposition between particular and universal, which is an important debate when it comes to policies of cultural diversity.

I asked almost all of research participants what is 'inclusion' for them, and the answers were different. Lots of them used descriptive definitions of inclusion, which describe "the variety of ways 'inclusion' is used in practice" (Ainscow et al. 2006, p. 14). This is actually just defining 'inclusion' through examples from immediate surroundings. Typical way in which my informants defined inclusion through examples is "they are very well accepted by their school mates, e.g., yesterday they have been doing their homework together". However, some unexpected examples of what inclusion may have emerged:

In German school in Belgrade where I also teach, 'inclusion' doesn't refer to foreigners ... But, for example, there are children who need additional support because they are neglected. This phenomenon is called 'Wohlstandsverwahrlosung' ... It is used for rich people's children, who because of neglection and emotional emptiness have issues. They grew up with nannies. They also need to be 'included'. (German teacher)

Prescriptive definitions, on the other hand, tend to find common patterns among various practices and provide theoretical comprehension of inclusion. Only three of my informants defined 'inclusion' in general. All three definitions emphasize the agency of the education system and view inclusion through the lens of educational policies, which are the top-down definitions of inclusion: 
Inclusion is the principle to enroll a child into prescripted education plan and program, while taking care about him the way he is. (School psychologist, 'Jovan Ristić' school)

Integration is when you adapt to the system, and inclusion is when the system adapts to you.

(The leader of the Group for Education of Minorities, Social Inclusion and Protection from violence and Discrimination in the Ministry of Education, Science and Technological Development of the Republic of Serbia)

Inclusion is having a possibility to access an education in an environment which makes it under pressure. (German teacher)

Finally, almost all of my informants emphasized the 'transit' character of asylum seekers' presence in Serbia. Serbia's status as a transit country may be the main reason why it is not necessary that asylum seeker children must learn the Serbian language before they enroll in schools. There is no need to put the effort into learning the language, because it is assumed that no asylum seeker want to stay in Serbia. Previous research has shown that most of the asylum seekers do not see their future in Serbia (Lažetić and Jovanović 2018, p. 18). Regardless, children are speaking Serbian, due to their long stay.

In Germany, they must learn the language first. That is called integration. Unlike that, "we in Serbia" give them an opportunity to go to school right away. Here, we put them in regular schools right away, even though they don't speak our language. That is inclusion.

(The leader of the Group for Education of Minorities, Social Inclusion and Protection from violence and Discrimination in the Ministry of Education, Science and Technological Development of the Republic of Serbia; the doctor of psychology)

Therefore, learning of native language as a precondition for school enrollment appears to be one more criteria for the distinction between 'inclusion' and 'integration'. According to this viewpoint, knowing the host's language is necessary for integration, while inclusion is less demanding and more sensitive toward cultural diversity.

\section{Conclusions}

Five important points arose from this research. First, inclusion in Serbia can be defined in narrow and in wide sense. Inclusion in narrow sense is when children with physical, cognitive, emotional, or behavioral disorders are included in school classrooms and when indivudual education plan (IEP) is practiced, in order to help them to overcome the difficulties. Inclusion in wide sense is when children from different cultural and linguistic backgrounds are included in classrooms. Second, when we talk about asylum seeker children, the term 'intercultural education' is more appropriate than the term 'inclusion', precisely because of the confusion that may arise from the first point. Third, other categories of children who need additional support in education, such as Roma children, sometimes overlap with asylum seekers in terms of education policies. Forth, asylum seeker children are not obliged to learn the Serbian language before they enroll in schools, because most of the asylum seeker families do not see their future in Serbia, but most of the children do learn it eventually, because they are surrounded by other children who speak Serbian all the time. Fifth, inclusion of asylum seeker children in schools is the most developed and the most positive aspect of refugee integration in Serbia.

Serbia adopted both asylum policies and inclusive education policies in order to access the EU. By including asylum seekers in elementary schools, Serbian government tends to affirm its competency to adapt to European laws and values. The official attitude of Republic of Serbia is that inclusion of refugee/asylum seeker children presents a fundamental aspect of asylum seeker's integration into Serbian society. It is more likely that asylum seeker children's enrollment in school is the only aspect of de facto refugee integration. However, in the Serbian context in 2019, 'integration' is just another word for 'accepting' or 'be kind to people in trouble'. There are no real integration policies. Asylum 
seekers get the job permit if they enter into asylum proceedure and after nine months spent in Serbia, so their possibilities to get a job are very limited. Also, asylum seekers are living in reception centers. The prospects for refugee/asylum seeker integration into Serbian society are very low. Asylum seekers, state officials, school staff and NGO staff stick to the attitude that Serbia is a transit country, even though there are no legal ways for asylum seekers to actually leave the country and move on.

However, this research shows that asylum seekers going to elementary school every day is a very positive process. The most of the asylum seekers and school staff are satisfied with this situation. It helps the children to have a more quality time in Serbia, while they wait to go further. It also helps them to feel normal. All people interviewed for the purpose of this paper perceive inclusion as the readiness of themselves and the state to accept asylum seeker children into their everyday lives. The values added to this notion are tolerance, kindness, solidarity, and hospitality. However, it is very unlikely that educational inclusion is sufficient for asylum seeker's equal participation in society.

Funding: This research received no external funding.

Conflicts of Interest: The author declare no conflict of interest.

\section{References}

Ainscow, Mel, Tony Booth, and Alan Dyson. 2006. Improving Schools, Developing Inclusion. London and New York: Routledge.

Armstrong, Derrick, Ann Cheryl Armstrong, and Ilektra Spandagou. 2011. Inclusion: By choice or by chance? International Journal of Inclusive Education 15: 29-39. [CrossRef]

Banks, James A. 2010. Approaches to multicultural curriculum reform. In Multicultural Education: Issues and Perspectives. Edited by James A. Banks and Cherry A. McGee Banks. Danvers: John Wiley, pp. 233-58.

Beznec, Barbara, Marc Speer, and Marta Stojić Mitrović. 2016. Governing the Balkan Route: Macedonia, Serbia and the European Border Regime. Belgrade: Rosa Luxemburg Stiftung Southeast Europe, ISBN 978-86-88745-21-5.

Catarci, Marco. 2014. Intercultural education in the European context: Key remarks from a comparative study. Intercultural Education 25: 95-104. [CrossRef]

Farrell, Ann. 2011. Transnational Displacement of Children: An Australian Perspective. In Global Migration and Education: Schools, Children and Families, 2nd ed. Edited by Leah D. Adams and Anna Kirova. Abingdon: Routledge, pp. 203-18, ISBN 0805858385.

Filipović, Jelena, Julijana Vučo, and Ljiljana Djurić. 2010. From language barriers to social capital: Serbian as the language of education for Romani children. In Selected Proceedings of the 2008 Second Language. Research Forum. Edited by Matthew T. Prior, Yukiko Watanabe and Sang-Ki Lee. Somerville: Cascadilla Proceedings Project, pp. 261-75, ISBN 978-1-57473-439-3.

Forbes, Joan, and Daniela Sime. 2016. Relations between Child Poverty and New Migrant Child Status, Academic Attainment and Social Participation: Insights Using Social Capital Theory. Education Sciences 6: 24. [CrossRef]

Janković, Marija. 2017. Serbia's Child Migrants Find Road to School Long. Balkan Insight. September. Available online: https://balkaninsight.com/2017/09/27/serbia-s-child-migrants-find-road-to-school-long-09-26-2017/ (accessed on 8 April 2019).

Lažetić, Marina, and Teodora Jovanović. 2018. Belgrade, Serbia: A Case Study of Refugees in Towns. Refugees in Towns Project. Boston: Feinstein International Center, Friedman School of Nutrition Science and Policy at Tufts University, Available online: https://static1.squarespace.com/static/599720dc59cc68c3683049bc/t/ 5ace0dd4f950b79e5858d6a9/1523453398380/Tufts+RIT+Belgrade\%2C+Serbia.pdf (accessed on 10 April 2019).

Macura Milovanović, Sunčica, Ivana Batarelo Kokić, Selma Džemidžić Kristiansen, Ibolya Gera, Estevan Ikonomi, Lejla Kafedžić, Tamara Milić, Xhavit Rexhaj, Ognen Spasovski, and Alison Closs. 2014. Dearth of early education experience: A significant barrier to educational and social inclusion in the Western Balkans. International Journal of Inclusive Education 18: 36-54. [CrossRef]

Maksin-Mićić, Marija. 2006. Peripheral zones of Serbian towns: Spatial development and way of life. Ethnologia Balkanica 10: 35-58.

Mikuš Kos, Anica. 2005. Activating Community Resources for the Well Being of Children and Stability. In Promoting the Psychosocial Well Being of Children Following War and Terrorism. Edited by Matthew J. Friedman and Anica Mikus-Kos. Amsterdam: IOS Press, pp. 11-32, ISSN 1574-5597. 
Milan, Chiara, and Andrea LP Pirro. 2018. Interwoven Destinies in the 'Long Migration Summer': Solidarity Movements Along the Western Balkan Route. In Solidarity Mobilizations in the 'Refugee Crisis'. Edited by Donatella della Porta. Basingstoke: Palgrave Macmillan, pp. 125-53. [CrossRef]

OECD. 2005. Students with Disabilities, Learning Difficulties and Disadvantages: Statistics and Indicators. Paris: Organisation for Economic Co-operation and Development, ISBN 92-64-00980-9. No. 539932005.

Polat, Filiz. 2011. Inclusion in education: A step towards social justice. International Journal of Educational Development 31: 50-58. [CrossRef]

Radoman, Vesna, Virxhil Nano, and Alison Closs. 2006. Prospects for inclusive education in European countries emerging from economic and other trauma: Serbia and Albania. European Journal of Special Needs Education 21: 151-66. [CrossRef]

Spasenović, Vera, and Slavica Maksić. 2013. Challenges of Democratisation: Development of Inclusive Education in Serbia. In Education in One World: Perspectives from Different Nations. Edited by Nikolay Popov. Sofia: Bulgarian Comparative Education Society, pp. 209-15, ISBN 978-954-92908-3-7.

Stajić, Jovana. 2018. Comparative Analysis of Migrant Integration through Education in Serbia and Turkey. Master's thesis, University of Belgrade, Faculty of Political Sciences, Regional Master's Program in Peace Studies, Belgrade, Serbia, September.

Stanojković, Darko, Ljiljana Panjković, Marina Todić, Ljiljana Arbutina, Tanja Ranković, Ivana Cenerić, Žaklina Veselinović, Jasminka Čekić Marković, Ana Vušurović Lazarević, Dr Snežana Vuković, and et al. 2017. Priručnik za škole u realizaciji stručnog uputstva za uključivanje učenika izbeglica/tražilaca azila u sistem obrazovanja i vaspitanja. Beograd: Ministarstvo prosvete, nauke i tehnološkog razvoja, ISBN 9788674520680. Available online: http://www.cep.edu.rs/public/Realizacija_Programa_dobrodoslice_ucenicima_migrantima. pdf (accessed on 9 April 2019). (In Serbian)

Stojić Mitrović, Marta. 2019. The Reception of Migrants in Serbia: Policies, Practices, and Concepts. Journal of Human Rights and Social Work 4: 17-27. [CrossRef]

Taylor, Sandra, and Ravinder Kaur Sidhu. 2012. Supporting refugee students in schools: What constitutes inclusive education? International Journal of Inclusive Education 16: 39-56. [CrossRef]

Vranješević, Jelena, and David Frost. 2016. Stories From Intercultural Education in Serbia: Teacher Leadership and Parent Participation. European Education 48: 63-78. [CrossRef]

Vranješević, Jelena, and Nataša Simić. 2018. Safe and Enabling Elementaty Education Environment for Refugee and Asylum Seeking Pupils. Belgrade: Save the Children, Available online: https://resourcecentre.savethechildren.net/sites/ default/files/documents/safe_and_enabling_school_environment_for_refugee_and_asylum_seeking_children_ in_serbia_research_summary_web.pdf (accessed on 21 April 2019). 